\title{
Improving the Mechanisms of Public-Private Partnership
}

\author{
Aliya Zyalilevna Minnibaeva ${ }^{1}$, Irina Yurievna Vaslavskaya ${ }^{2}$, Irina Alexandrovna Koshkina ${ }^{3} \&$ Artur Faridovich $^{3}$ \\ Ziyatdinov $^{3}$ \\ ${ }^{1}$ Economic Office, Naberezhnye Chelny Institute, Kazan Federal University, Russia \\ ${ }^{2}$ Economic Office, Higher School of Economics and Rights, Department of Economics of Enterprises and \\ Organizations, Naberezhnye Chelny Institute, Kazan Federal University, Russia \\ ${ }^{3}$ Department of Economics of Enterprises and Organizations, Naberezhnye Chelny Institute, Kazan Federal \\ University, Russia
}

Correspondence: Aliya Zyalilevna Minnibaeva, Undergraduate of economic office, Naberezhnye Chelny institute of KFU, Russia. E-mail: aliy987898@mail.ru

Received: October 9, 2020

Accepted: December 2, 2020

Online Published: January 14, 2021

doi:10.5430/ijfr.v12n2p242

URL: https://doi.org/10.5430/ijfr.v12n2p242

\begin{abstract}
Development of the Russian economy causes the growth of public requirements and structural changes connected with it directed to an increase in the efficiency of social and economic tasks solution. Need of partnership of the state and private business development for the solution of problems in the social and economic sphere predetermines by the insufficiency of opportunities of the public (budgetary) financing of investment projects, large-scale and significant for society. The public-private partnership (PPP) acts as one of the modern economic mechanisms allowing realizing the interaction of the state and business. The PPP, on the one side, represents a special form of influence of state authorities and management for the purpose of stimulation of business activity, and with another, acts as the economic mechanism of the solution of social and economic tasks. The article is devoted to the consideration of the public-private partnership mechanism as one of the most modern methods of economic activity state regulation which basis the basic coordination principle of the parties interests and allowing to combine interests and technologies of business. Need and the prospects of further development of mechanisms of state-private partnership on the basis of the state strategic planning are proved. Special attention is paid to the interrelation of development of public-private partnership and need of theoretical scientific research in the field of improvement of institutional, ensuring its realization. It is shown that the role of the mechanism of public-private partnership in the economy is defined, first of all, by its elements as subjects and objects of public-private partnership, priority spheres of realization. Authors allocate and describe a number of aspects of the mechanism of functioning of public-private partnership, namely: organizational and legal, financial and investment, technical and organizational, regional. In the article, the main problems connected with the development of the mechanism of PPP, including with lack of the description of concrete mechanisms of use of the majority of forms of PPP and lack of regulation of questions of division of powers between public authorities and business are allocated and proved.
\end{abstract}

Keywords: economy, state, private business, PPP-projects, problems, mechanisms of state-part partnership

\section{Introduction}

One of the most important issues in the world today for development is the creation of infrastructure and infrastructure; From intercity and suburban routes to information technology infrastructure and the like. No economy in the world can thrive without building the necessary infrastructure. From the past to the present, for reasons such as high costs, long payback period, weak financial strength and lack of protection of laws and regulations from the private sector, the creation of infrastructure has been the responsibility of the public sector or the government and government and public organizations (Kolesnikov et al., 2018; Lousada, 2020). But today, it is clear that the public sector, without the help of the private sector, cannot create optimal infrastructure and infrastructure, because many specialties are stronger in the private sector and the private sector usually has a better ability to manage resources and time in projects. It can be concluded that the best way to create optimal infrastructure and infrastructure is to use all specialties in the public sector (including the national government, local government and municipalities) and in the private sector, to use the legal support of the public sector and most importantly financial resources. Both parts. That 
is why today the issue of "public-private partnership" is so important that many large financial and academic institutions have set up training courses for it (Hodge \& Greve, 2017; Wang et al., 2018).

Public-Private Partnership (PPP) has emerged around the world in response to the lack of new infrastructure and the need to rebuild existing infrastructure. There is no clear and unique concept for PPP (Public and Private Partnership), but in short, it is a model for providing infrastructure or services (Keers et al., 2018; Rosell \& Saz-Carranza, 2020). The public and private sectors, through partnerships or organizations, ensure citizens' access to facilities (infrastructure) or services. PPP models mainly serve public interest missions, and this is one of the salient features of PPP models. For example, these models are used in projects related to roads, railways, airlines, water and sewage, energy waste, health, security and prisons. The government is the ultimate supporter of providing these services to the private sector. In these models, the government delegates responsibility for designing, financing, operating infrastructure, or services to the private sector. In some of these models, not all responsibilities are assigned to the private sector, and areas such as financing and design are performed by the public sector (Jokhio et al., 2016). PPP is becoming a solution to overcome public sector budget constraints, using the skills and expertise of the private sector. PPPs are also looking for solutions to access public services. Although the main impetus for the expansion of three-party contracts should be greater efficiency in the use of public funds, the reality is that PPP projects are used as a shortcut to overcoming public budget constraints. Problems may occur in the long and medium-term, especially during the review of $3 p$ contracts, which increases the financial burden through the procurement model (Yuan et al., 2009; Cheng et al., 2016; Osei-Kyei \& Chan, 2017; Berezin et al., 2018).

In every single country, owing to specifics of its development and national peculiarities of the legislation, the approaches to understanding and definition of mechanisms of PPP can differ. The essential distinction is in what in some countries of PPP is understood as an alternative to direct budget financing of infrastructure projects, and in others - as partnership option between the state and business at the implementation of projects in various forms.

It should be noted that at the federal level legally the concept of public-private partnership is not fixed though it also is widely applied in various regulations, in particular in the Budget Code of the Russian Federation and a number of federal target programs. At the same time in these documents, it is only about activity implementation «based on the principles of public-private partnership». In broad understanding, the public-private partnership can be considered as any possible interaction of business, authorities and a society, therefore. In this sense, the mechanism of PPP «represents the instrument of interaction defining the principles, rules and the sequence of performance of certain actions between various subjects of PPP, limited to the volume and/or the sphere of their interests and normative legal acts» (Lomovceva \& Gerasimenko, 2015; Wu et al., 2017; Jiang, 2017).

For interpretation of PPP narrower approach when the PPP is understood as equal mutually beneficial cooperation between the state and private business in the arrangement course of public infrastructure and providing public services on division condition of risks and responsibility between the state and business (Bychkova, 2015) is more often put into practice.

In foreign practice, there is a positive experience of implementation of projects of PPP at the solution of global social and economic tasks. Researches show that the main difference in projects of PPP is the number of obligations which undertake the state and business as partners (Renda \& Schrefler, 2006) acts.

In modern conditions, the integration of resources of the state and private business allows to successfully solve any problems of implementation of large-scale infrastructure projects of the all-Russian value. Considering that PPP projects are carried out in those spheres of the economy where considerable financial resources are necessary, and the state cannot finance them completely from the budget, the value of PPP constantly increases in Russia, creating the basis for the development of the economy. In this plan, the public-private partnership is the universal and effective mechanism for the achievement of the maximum result within the interaction of the state and business in the social and economic sphere (Khan et al., 2020).

The mechanism of public-private partnership should be considered as a system that defines an order of interaction of subjects of PPP concerning an object of PPP in the conditions of the developed institutional environment (Nikolaev \& Bochkov, 2017). The list of subjects and objects of PPP, an order of the relations between them, forms of cooperation of the state and private business and also mechanisms of public-private partnership in the Russian Federation are defined by laws and regulations (Federal law of July 21, 2005, No. 115-FZ; Federal law of July 13, 2015, No. 224-FZ).

The mechanism of PPP using analysis at the federal and regional levels shows that at the effective structure of this mechanism and the optimum choice of forms of PPP, its use is favourable to the state, the private sector and society. 
Granting public benefits by the state due to attraction and use of the private capital allows it to fulfil national objectives. At the same time, risk management of projects from the state guarantees to private business decrease in investment risks.

Mechanisms of PPP can be considered as a basic design of attraction of off-budget investments into the development of different types of infrastructure and development of various territories. It allows to attract on favourable conditions private investments and competencies for creation of qualitative public infrastructure and rendering various services based on the created property according to the established time frames and the budget (Mu et al., 2011). At the same time, development and implementation of projects of PPP in practice are accompanied by the whole complex of the problems connected with insufficiently adequate institutional providing and study of the regulatory framework defining mechanisms of public-private partnership.

On the basis of the above, there is an objective need of carrying out the scientific research aimed at the development of mechanisms of realization of PPP on the basis of improvement of institutional providing taking into account influence of all possible factors providing its realization.

\section{Methods}

PPP projects are thought to have been developed in the United Kingdom in the 1990s. In fact, this is true, given the current and complex structure of projects. However, it has a much longer history as a kind of agreement between the public and private sectors, with responsibilities later transferred to the government. In the fifteenth century, you may find "concession models", in which the grantor (king) allows ships to pay rent by exploring unknown territories. This model was widely used until 1990. Initially, countries such as the United Kingdom, Canada, Australia, Spain, Portugal, and more recently, all of South America, Asia, Africa, and the United States used this model. There is no universally accepted definition of public-private partnerships. By broad definitions, we seek to capture the core elements of public-private partnerships. Public-private partnerships are business transactions between a public and a private sector in which the private sector:

- Provides services for a significant period of time (usually provided by the public sector).

- It assumes construction risk, operational risk and commercial risk.

- The payroll is provided directly to the private sector by government officials, either through user fees, or a combination of both.

Infrastructure services such as roads, electricity, telecommunications and water resources are traditionally provided by the government. Due to the quality issues related to the services provided to the public, the large demand gap and the financial crisis due to the inability of the public sector to provide these services, efforts are being made to transfer such services as public and private partnerships to the private sector. This transition takes place in the provision of services for a relatively long period of 30 years for a road project and longer in other sectors such as the airport project. Concession or exploitation concessions in these projects have been transferred to the private sector for 30 years as a PPP model with the possibility of concession extensions over a 30-year period.

Risk transfer is at the heart of the structure of a PPP project. Optimally, you should move the risk to a direction that has more control over the risk factor. According to this principle, risks that are controlled by the private sector should be transferred to this sector. Therefore, after the transfer of responsibilities for infrastructure services, construction, commercial and operational risks must be transferred to the private sector.

Unbridled time and costs in construction are the most important killers of public construction, and the public sector wants to optimally transfer this risk to the private sector through construction contracts at a fixed price. This transfer is done by depositing the surplus-value of the services provided by the public sector and the services provided by the private sector to the private sector. Operating infrastructure risks are often costly for the government. Allocating some of these risks to a private sector that can better manage them can reduce the overall cost of the project to the government.

Infrastructure services must be paid for by the government or users or both. These payments are necessary when the infrastructure is not provided by the public sector. However, when the private sector provides infrastructure services, it must be made clear that if the government wants to keep user costs down, our payment to the private sector will be made differently through direct budget payments. Some of the advantages of PPP are shown in Figure 1. 


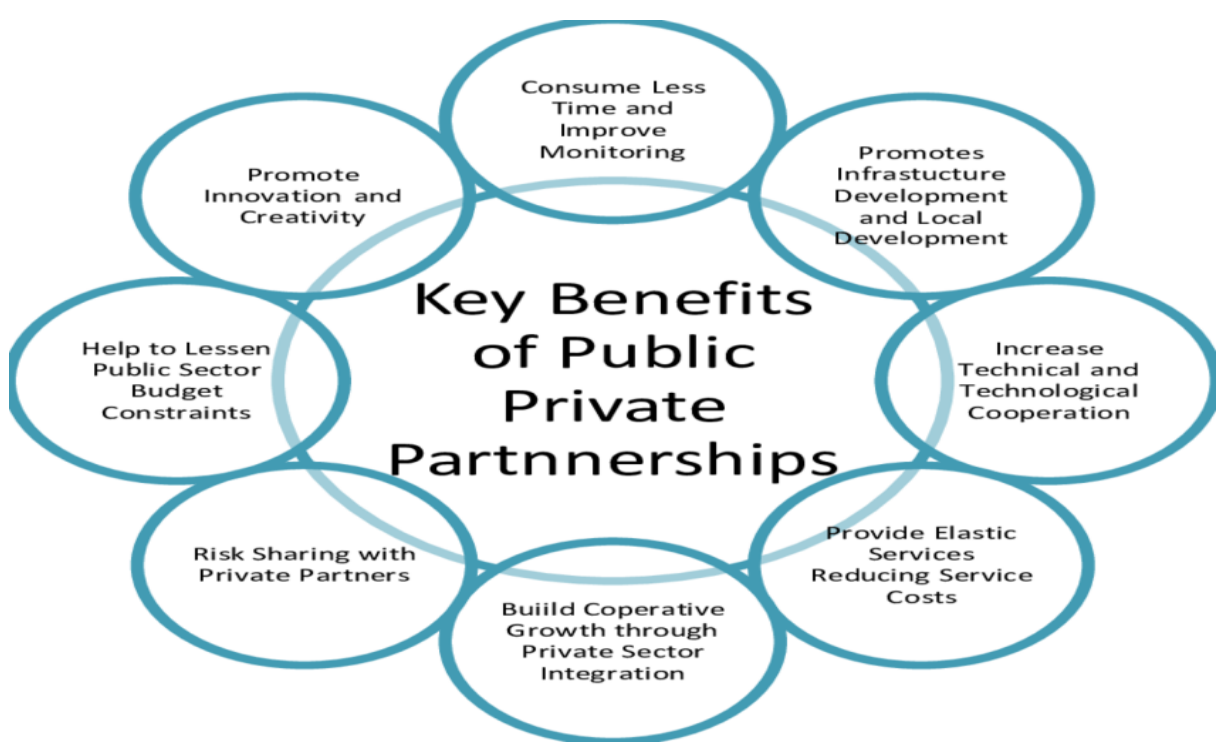

Figure 1. The key benefits of PPP

As mentioned earlier, in this paper, it was tried to devote to the consideration of the public-private partnership mechanism as one of the most modern methods of economic activity state regulation which basis the basic coordination principle of the parties interests and allowing to combine interests and technologies of business. It is obvious that as information sources when writing article training and scientific materials on a research subject, periodic literature and data of the rating and analytical agencies acted. Theoretical and methodological bases of studying the theory of public-private partnership in literature are presented by a frame of reference of many scientists such as Bouf (2003), Suriak (2015), Kessey (2017), Liu \& Wang (2018) etc. In this paper, the mechanism of implementation of projects of PPP is actively investigated in Russia and in foreign countries.

\section{Results and Discussion}

Ample opportunities of utilizing the mechanism of PPP are caused by its nature-based on social and economic interaction of the state and private business and also almost unlimited forms of its realization in various spheres of the economy. Development of PPP is defined by a number of the factors influencing the expansion of scales and forms of interaction of the state and business (Druzhkov \& Eremin, 2019), defining from which the possibility of the displaced economy mechanism to build up the economic relationship between private business and the state is. Figure 2 shows the Values of partnership index (IP) that measures the level of development of PPP in different countries. 


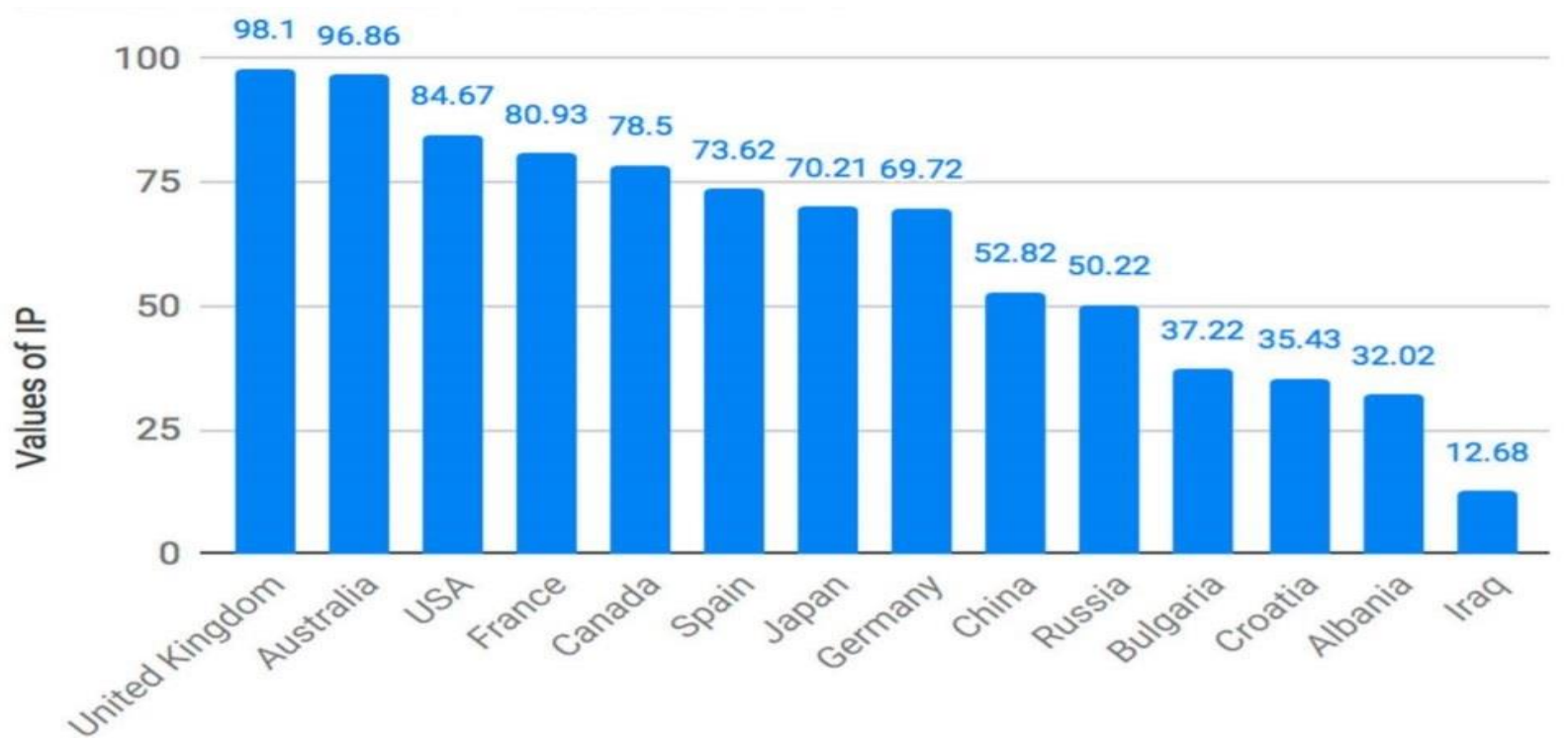

Figure 2. Representation of Values of IP that measures the level of development of PPP in different countries

The resources involvement of the private sector in processes of reproduction in the industries and spheres which are owned by the state and local authorities and also use of a private enterprise initiative for an increase in efficiency of expenditure of budgetary funds is defined by various forms and models of realization of public-private partnership. Combination of efforts and resources of business and the state within concrete PPP projects forms their additional competitive advantages. The typical financing structure of a PPP project is shown in Figure 3.

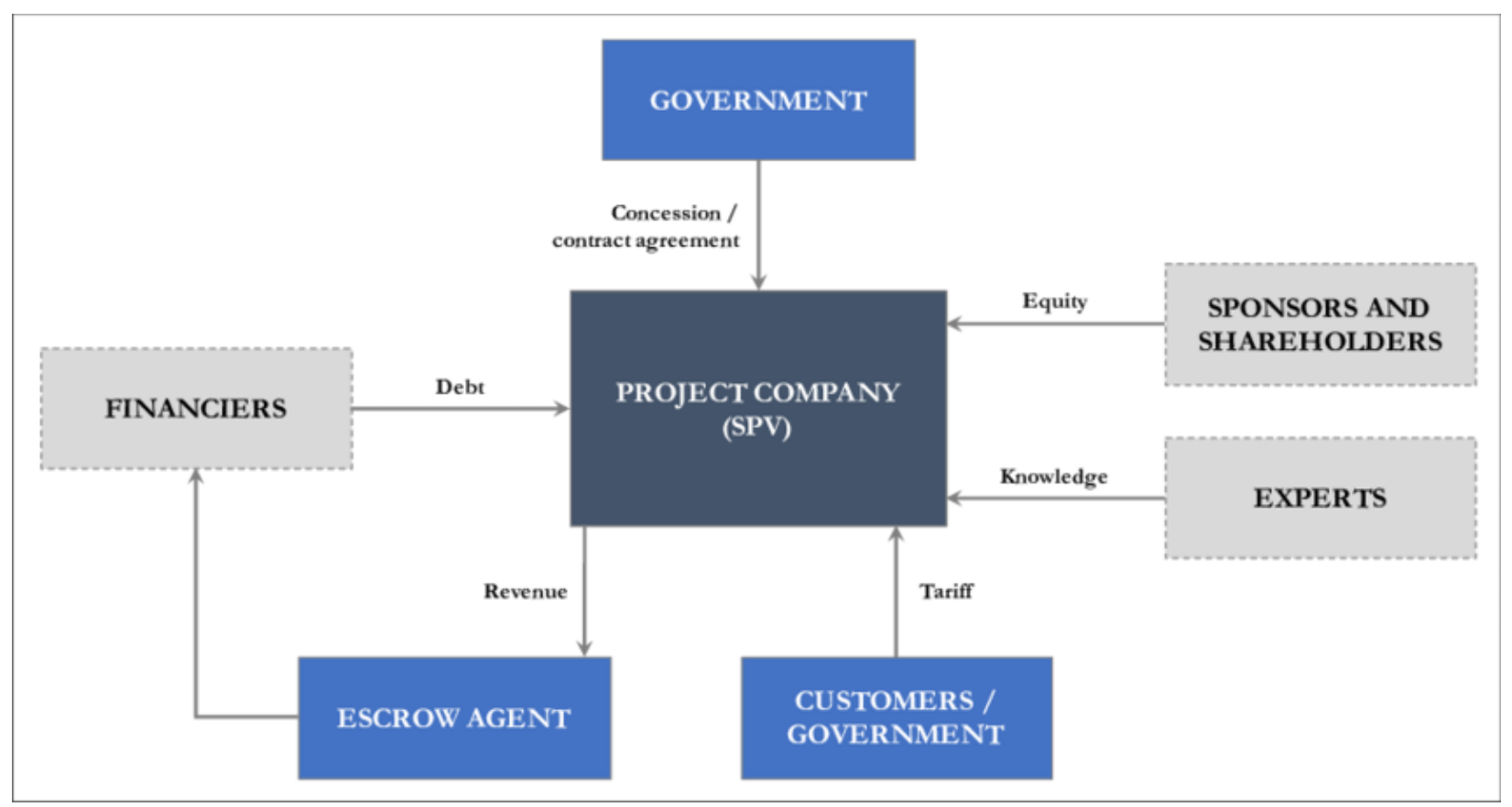

Figure 3. The typical financing structure of a PPP project (United Nations ESCAP, 2011)

Business in comparison with the state institutes has bigger mobility, speed of decision-making, ability to innovations, aspiration to the search of technical and technological improvements for ensuring competitiveness. The state, in turn, can provide more successful projects implementation of PPP by the creation a stable regulatory legal base, holding 
organizational actions, including for interaction with civil society and also uses of financial and economic levers: subsidies, guarantees, incentive taxation and other types of support.

The Russian Federation suffers a shortage of investments into infrastructure facilities. During the period from 2020 to 2040, this shortage will annually make $1.9 \%$ of GDP, according to Global Infrastructure Hub. For comparison, in Australia and New Zealand this level for the same period will be $0.36 \%$ of GDP, in Great Britain - $0.16 \%$ of GDP, and in Canada - 0.04\% of GDP (Report of «Global Infrastructure Outlook», 2017).

The PPP has a wide range of various forms: contracts, rent and leasing relations, concession (concession agreement (CA), production sharing agreement (Production Sharing Agreement)), state-private enterprises, and special economic zones. The model choice of PPP is made depending on in what spheres the agreement is implemented. Practically all territorial subjects of the Russian Federation use the KS mechanism for the creation or reconstruction of infrastructure facilities. At the same time only at ten regions (12\%) more than $100 \mathrm{KS}$ (considering municipal concessions) are concluded (The review of NAKDI, 2020). It, certainly, demonstrates to the unsolved potential of the mechanism of PPP realization for construction of infrastructure.

In terms of economic feasibility when choosing form freedom of contractual regulation, the extent of increase in appeal to creditors (lack of restrictions on some instruments of providing) and also a possibility of effective regulation of competitive procedures at the regional level is considered by PPP, for example, (Ivanov et al., 2019). As practice shows, the average realization term of PPP project is 5-15 years. It is obvious that for this period, both the internal and external political and economic factors having a direct impact on conditions of development of state-part partnership can change. So, for example, in connection with a pandemic of this year, it is necessary to adjust the course of implementation of national projects, the majority of which has to be realized on the principles of public-private partnership.

As the PPP is an important element of investment policy, development of long-term planning that obligations assumed at the beginning of the implementation of the project were supported is necessary, and conditions of their existence did not change. In this case, the state has to as the participant of this agreement to assume certain risks (Lloyd Owen, 2016). Risks of the early termination of the project belong to such risks. This group of risks relates to order, use of the constructed objects, and objects of social infrastructure. Besides, the currency risks and risks connected with conditions change of refinancing of the project, which is not depending on the private investor are great. In turn, the development of strategic planning allows coordinating in the long-term strategic objectives of the state and business based on the program in which procedures of implementation of specific projects are also described.

The development prospects of the relations of the state and business in no small measure depend on the solution of questions of the investments connected with protection, development of settlement mechanisms of investment disputes. At the regional level one of the most important questions for today - complex development of territories of the Russian Federation. In this case, mechanisms of public-private partnership are capable of giving serious support to the development of regional infrastructure, but on the solution condition of organizational and legal and financial aspects of the implementation of regional projects.

\section{Summary}

Now the development of public-private partnership mechanisms in the Russian Federation faces problems of both objective and subjective character. It is necessary to carry to the main of them:

- Strategy lack of stage-by-stage introduction and use of different forms of PPP;

- Not development at the legislative level of development accurate priorities of the industries and spheres in which interaction of the state and private business is expedient;

- Inconsistency of the concession, budget and land legislation;

- Lack of a reasonable technique of complex verification of financial proposals of contestants regarding their realness and also an imbalance of technical and financial selection criteria of bids;

- Lack of experience of realization and management of such projects, absence of qualified specialists in the field of public-private partnership, etc. (The review of NAKDI, 2020).

Although at the regional level the separate normative legal acts fix a concept of PPP, its forms, an order and participation conditions of the subject in public-private partnerships are accurately not defined. Besides, the laws of subjects regulating legal relationship in the PPP sphere are non-uniform on structure, in them, conditions of the entry of the region into public-private partnerships significantly differ, guarantees and distribution of risks are not registered in many that prevent the wide circulation of PPP. The state is frequent and private partners allow the miscalculations 
inefficiency of using projects of PPP connected with a rise in the price of projects in comparison with its initial cost. One of the main problems of domestic PPP is the understanding of PPP created at most of its participants as forms of participation of business in the problem's solution of nation-wide scale mainly at the expense of budgetary funds today.

Having analyzed advantages and problems in the sphere of realization of PPP, it is possible to draw a conclusion that in Russia the mechanism of attraction of investments of the private sector not fully is implemented in interaction with the state which is capable of providing financial aid and is ready to assume a part of risks. More professional approach to the form's selection of financing and implementation of projects is necessary for more effective using PPP.

For further development of the mechanism of PPP in Russia, including, at the regional level, it is necessary to solve the following problems:

1. To develop the strategy of application of schemes of PPP the relevant industries in the sectors of the economy at first.

2. To develop the regulatory framework regulating PPP, to provide its reliable functioning.

3. To develop the scheme of the projects monitoring implemented according to schemes of PPP.

4. To provide the introduction of an adequate system of the tariffs for the use of objects of transport and other infrastructure constructed according to schemes of PPP.

5. To develop the mechanism of the public offer (within PPP) projects to investors.

6. To create an adequate system of subsidizing and the corresponding tools in order that socially vulnerable population groups did not suffer from the implementation of projects of PPP (Mu et al., 2011).

\section{Conclusions}

Now «the importance of PPP should be treated in a context of the need for formation and expansion of organizational structures of the partnership (cooperation) the state and private business which potential is huge, and extent of realization it is insignificant» (Public-private partnership, 2016). It is shown not only in the companies' organization of this kind but also a realization by the business of socially responsible policy. Besides, public-private partnership The effective mechanism for the development of the social sphere as it relates to the development of projects of public importance. The PPP allows combining interests of both society, and business and allows them to create in bigger volume the socially important benefits in the conditions of insufficient financing of their production from the state.

The mechanism advantages of public-private partnership are widely used in infrastructure projects, the social sphere, and the sphere of public services, telecommunications and communication. The state involves not only additional financing from outside of private business but also the best administrative practices, the latest technologies.

However, as the Russian practice shows, the state cannot always be considered as the reliable partner; therefore the creation of competitive offers for realization within the public-private partnership is obviously important in the direction of development.

On this background the increasing inefficiency of the state due to involvement of private investors to the solution of public problems and economy of government budget means at the same time can serve as an important factor in the acceleration of economic growth in Russia (Public-private partnership, 2016).

\section{Acknowledgements}

The work is performed according to the Russian Government Program of Competitive Growth of Kazan Federal University.

\section{References}

Berezin, A., Sergi, B. S., \& Gorodnova, N. (2018). Efficiency assessment of public-private partnership (PPP) projects: The case of Russia. Sustainability, 10(10), 3713.

Boeuf, P. (2003, November). Public-private partnerships for transport infrastructure projects. In Contribution to the seminar, "Transport infrastructure development for a wider Europe" in Paris (pp. 27-28).

Bychkova, A. N. (2015). Economic mechanism: definition, classification and application. Vestn. Omsk. un-that. It is gray.: Economy, 4, 37-43.

Cheng, Z., Ke, Y., Lin, J., Yang, Z., \& Cai, J. (2016). Spatio-temporal dynamics of public private partnership projects 
in China. International Journal of Project Management, 34(7), 1242-1251.

Druzhkov, K., \& Eremin, V. (2019). Public-private partnership - an actual form of implementation of infrastructure projects. Ekonomika i matematicheskie metody, 54(4), 111-115.

Federal law of July 13, 2015 No. 224-FZ. About Public-private Partnership, Municipal and Private Partnership in the Russian Federation and Introduction of Amendments to Separate Acts of the Russian Federation.

Federal law of July 21, 2005 No. 115-FZ. About Concession Agreements.

Hodge, G. A., \& Greve, C. (2017). On public-private partnership performance: A contemporary review. Public Works Management \& Policy, 22(1), 55-78.

Ivanov, O., Zavyalova, E., \& Ryazantsev, S. (2019). Public-Private Partnership In The Countries Of The Eurasian Economic Union. Central Asia \& the Caucasus (14046091), 20(2).

Jiang, Y. (2017). Selection of PPP projects in china based on government guarantees and fiscal risk control. International Journal of Financial Research, 8(1), 99-111.

Jokhio, S., Abro, M. M. Q., \& Alaali, L. (2016). Managing risk in livestock farming: The role of insurance companies. International Journal of Financial Research, 7(2), 64-72.

Keers, B. B., \& van Fenema, P. C. (2018). Managing risks in public-private partnership formation projects. International Journal of Project Management, 36(6), 861-875.

Kessey, E. K. (2017). The Dynamics of Change: Exploring the Successes and Failures of Business Process Re-Engineering in PPP Infrastructure Projects. In Advances In Public-Private Partnerships (pp. 98-111). Reston, VA: American Society of Civil Engineers.

Khan, Z., Ali, M., Kirikkaleli, D., Wahab, S., \& Jiao, Z. (2020). The impact of technological innovation and public private partnership investment on sustainable environment in China: Consumption - based carbon emissions analysis. Sustainable Development, 28(5), 1317-1330.

Kolesnikov, Y. A., Pavlyuk, A. V., Radachinsky, Y. N., \& Rodionova, N. D. (2018). Problems of implementation of public-private partnership in Russia.

Liu, T. T., \& Wang, Y. C. (2018). Examining critical factors affecting knowledge transfer in public-private partnership (PPP) projects. In Proceedings of the 21 st International Symposium on Advancement of Construction Management and Real Estate (pp. 727-744). Springer, Singapore.

Lloyd Owen, D. A. (2016). Public-private partnerships in the water reuse sector: a global assessment. International Journal of Water Resources Development, 32(4), 526-535.

Lomovceva, O. A., \& Gerasimenko, O. A. (2015). Priorities and public-private partnership mechanisms in the formation of innovative industrial complex of region. The BSU Scientific Bulletin, 13(210), 35.

Lousada, I. (2020). The Amyloidosis Forum: a public private partnership to advance drug development in AL amyloidosis. Orphanet Journal of Rare Diseases, 15(1), 1-13.

Mu, R., De Jong, M., \& Koppenjan, J. (2011). The rise and fall of Public-Private Partnerships in China: a path-dependent approach. Journal of Transport Geography, 19(4), 794-806.

Nikolaev, A. I., \& Bochkov, S. O. (2017). Public-private partnership in the Russian Federation: economic contents and legal support. Real estate and investments. Legal Regulation, 3, 21-32.

Osei-Kyei, R., \& Chan, A. P. (2017). Implementing public-private partnership (PPP) policy for public construction projects in Ghana: critical success factors and policy implications. International Journal of Construction Management, 17(2), 113-123.

Renda, A., \& Schrefler, L. (2006). Public-private partnerships. Models and trends in the European Union. The European Parliament, 5, 161.

Rosell, J., \& Saz-Carranza, A. (2020). Determinants of public-private partnership policies. Public Management Review, 22(8), 1171-1190.

Suriak, A. (2015). Ways and Implementation Mechanisms of Public-Private Partnership Models in Ukraine. Scientific Journal of Polonia University, 15(4), 75-91.

Wang, H., Xiong, W., Wu, G., \& Zhu, D. (2018). Public-private partnership in public administration discipline: A literature review. Public Management Review, 20(2), 293-316. 
Wu, Y., Li, L., Xu, R., Chen, K., Hu, Y., \& Lin, X. (2017). Risk assessment in straw-based power generation public-private partnership projects in China: A fuzzy synthetic evaluation analysis. Journal of Cleaner Production, 161, 977-990.

Yuan, J., Zeng, A. Y., Skibniewski, M. J., \& Li, Q. (2009). Selection of performance objectives and key performance indicators in public-private partnership projects to achieve value for money. Construction Management and Economics, 27(3), 253-270.

\section{Copyrights}

Copyright for this article is retained by the author(s), with first publication rights granted to the journal.

This is an open-access article distributed under the terms and conditions of the Creative Commons Attribution license (http://creativecommons.org/licenses/by/4.0/). 